Original Article

\title{
Nest refuse of Acromyrmex balzani (Hymenoptera: Formicidae) increases the plant vigor in Turnera subulata (Turneraceae)
}

\author{
O substrato de descarte de Acromyrmex balzani (Hymenoptera: Formicidae) aumenta o \\ vigor da planta Turnera subulata (Turneraceae)
}

R. S. Santos ${ }^{a}$ (i) and L. Sousa-Souto ${ }^{a *}$ (1)

anniversidade Federal de Sergipe - UFS, Departamento de Ecologia, Programa de Pós-graduação em Ecologia e Conservação, Laboratório de Ecologia de Insetos, São Cristóvão, SE, Brasil

\begin{abstract}
Some studies report the positive effect of organic residues from ant nests on soil properties and on the structure of the adjacent plant community in field experiments, but there is a gap about the effect on individual species. The purpose of the present study was to compare the soil nutrient content and the development of Turnera subulata Smith, an ornamental species, in the presence of the nest refuse (basically composed of fragments of grass leaves and the symbiotic fungus) produced by the leaf-cutting ant Acromyrmex balzani (Emery, 1890) or in control soil through a greenhouse pot experiment. The experiment was carried out with two treatments: control soil and soil with $25 \%$ of nest refuse. The plants were kept in $1 \mathrm{~L}$ pots for 90 days. We evaluated the parameters: plant height, stem diameter, root length, number of leaves, dry weight of the root, dry and fresh aboveground biomass. Additionally, the relative chlorophyll content and leaf nutrients were used as nutritional parameters. As a result, plants that grew in the soil with nest refuse showed significant higher values of all parameters evaluated when compared to the control treatment ( $\mathrm{p}<0.001$ ). We conclude that this biofertilizer contributed to the production of more vigorous plants, being able to act on the local dynamics of nutrients in the ecosystems where A. balzani occurs. As it is relatively abundant and easy to collect, the refuse of A. balzani has the potential to be used as an alternative substrate in the production of shortlife cycle plants.
\end{abstract}

Keywords: plant fitness, regeneration, leaf-cutting ants, refuse dumps, soil fertility.

\begin{abstract}
Resumo
Alguns estudos relatam o efeito positivo de resíduos orgânicos de formigueiros nas propriedades do solo e na estrutura da comunidade de plantas adjacentes em experimentos de campo, mas há uma lacuna sobre o efeito em espécies individuais. O objetivo do presente estudo foi comparar o desenvolvimento de Turnera subulata Smith, uma espécie ornamental, na presença do substrato de descarte (SD) de formigueiros produzido pela formiga cortadeira Acromyrmex balzani (Emery, 1890) por meio de experimento em casa de vegetação. O experimento foi conduzido com dois tratamentos: solo controle e solo com 25\% de SD. As plantas foram mantidas em vasos de $1 \mathrm{~L}$ por 90 dias. Foram avaliados os parâmetros: altura da planta, diâmetro do caule, comprimento da raiz, número de folhas, massa seca da raiz, biomassa seca e fresca da parte aérea. Além disso, o conteúdo relativo de clorofila e os nutrientes foliares foram usados como parâmetros fisiológicos. Como resultado, as plantas que cresceram no solo com SD apresentaram valores significativamente maiores de todos os parâmetros avaliados quando comparadas ao tratamento controle $(\mathrm{p}<0.001$ ). Concluímos que esse biofertilizante contribuiu para a produção de plantas mais vigorosas, podendo atuar na dinâmica local de nutrientes nos ecossistemas onde A. balzani ocorre. Além disso, por ser relativamente abundante e fácil de coletar, o SD de A. balzani tem potencial para ser utilizado como biofertilizante na produção de plantas de ciclo de vida curta.
\end{abstract}

Palavras-chave: performance de plantas, regeneração, formigas cortadeiras, lixo de formiga, fertilidade do solo.

\section{Introduction}

Nutritional deficiencies in soils are among the main limiting factors for the functioning of tropical ecosystems, negatively affecting the species diversity and the structure of plant communities (Walker and Syers, 1976; Dalling et al., 2016; Delavaux et al., 2017).
Reduced amounts of nutrients and soil organic matter in the soil can affect the growth, reproduction and chemical composition of plants, and external inputs or the constant cycling of nutrients is crucial for the maintenance of these ecosystems (Brearley et al., 2003; Cleveland et al., 2013;

*e-mail: leandrosouto@ufs.br

Received: October 19, 2020 - Accepted: March 1, 2021 
Delavaux et al., 2017). Although the causes of nutritional deficiencies in the soil are diverse, it is known that in newly disturbed environments this limitation is partly attributed to the reduction of soil organic matter content and the low rate of nutrient mineralization (Neill et al., 1995, 1996; Sousa-Souto et al., 2013; Delavaux et al., 2017). The negative effects of low availability of nutrients in the soil in these environments are often mitigated by the activities of "ecosystem engineers" (Lavelle, 1997).

Despite being considered important agricultural pests, leaf-cutting ants (Atta spp. and Acromyrmex spp.) can also act as ecosystem engineers in natural environments and provides ecological services (Wirth et al., 2007; Alho, 2008; Meyer et al., 2011, 2013). For example, some field experiments report that changes in the physical-chemical structure of soils affect the structure of adjacent vegetation, whether due to the construction and maintenance of nests, forming micro habitats rich in nutrients (Moutinho et al., 2003; Sousa-Souto et al., 2008; Meyer et al., 2013; Farji-Brener and Werenkraut, 2015), or by opening clearings in the forest (Corrêa et al., 2010; Meyer et al., 2011).

For maintenance and expansion of the colonies, leaf-cutting ants continuously collect fragments of vegetation and transport them to their fungus chambers. The material resulting from fungal decomposition, including seeds, leaves and arthropod carcasses, is accumulated in piles within nests or outside them (Moutinho et al., 2003; Sousa-Souto et al., 2008; Poderoso et al., 2009; Pirk and Farji-Brener, 2013). These biological structures, popularly identified as nest refuse (NR) or nest waste, can form points in the landscape where the availability of nutrients is fast and constant (Sousa-Souto et al., 2008; Cerda et al., 2012, Farji-Brener and Werenkraut, 2015). However, the resulting benefits to vegetation can vary, since access to waste will depend on several factors, such as depth of the root system, type of plant layer, the nutritional aspects of the plant species involved as well as the place of disposal of the refuse (if outside the colony or in the underground chambers of the nests) (Coutinho, 1984; Sternberg et al., 2007; Farji-Brener and Werenkraut, 2015).

In general, changes in vegetation structure due to NR are mainly related to greater availability of nitrogen, phosphorus and potassium (Sternberg et al., 2007; Farji-Brener and Ghermandi, 2008; Farji-Brener and Werenkraut, 2015). This ease of access to nutrients often increases the abundance, diversity and productivity of plants, as well as speeding up the nutrient cycle in various ecosystems, including arid and newly disturbed regions (Moutinho et al., 2003; Cerda et al., 2012; Santos et al., 2019). However, an aspect that is still little addressed is the understanding of the isolated effect of NR (in a greenhouse experiment), mainly to explain changes in the development and reproduction of individual plant species (Farji-Brener and Werenkraut, 2015, 2017). Recent studies indicate that pioneer plant species showed a marked development when kept in contact with NR, verified by higher biomass above ground (Santos et al., 2019), a greater amount of fruits (Farji-Brener and Ghermandi, 2008) and a higher number of flowers (Fernandez et al., 2018). These improvement in the performance of plant species in these studies is attributed to a greater supply of nutrients from NR. However, there are still gaps to be filled, such as, for example, the evaluation of the vigor of plants that grow on nest refuse, by observing the morphological and nutritional attributes of the plants. Once in contact with a nutrient-rich spot, plants can invest more in growth and reproduction, probably having a greater physiological capacity in terms of absorption and storage of nutrients in leaf tissues (Farji-Brener and Werenkraut, 2015, 2017).

In the present study, we tested the hypothesis that the NR produced by Acromyrmex balzani (Emery, 1890) in the region of study has a positive effect as a biofertilizer, changing soil nutrient content and increasing the vigor of an ornamental and pioneer herbaceous species Turnera subulata Smith. This hypothesis predicts that plants cultivated with NR will present better development characteristics (height, stem diameter, number of leaves, root length and fresh and dry biomass), associated with nutritional attributes (high levels of chlorophyll, $\mathrm{N}$ and P content), compared to plants grown on the control substrate.

\section{Material and Methods}

\subsection{Study species}

\subsubsection{Acromyrmex balzani (Emery, 1890) (Formicidae: Attini)}

The leaf-cutting ant A. balzani is widely distributed in Brazil (Rando and Forti, 2005), commonly found in pasture or anthropogenic areas (Sousa-Souto et al., 2013). Their colonies are relatively small when compared to other cutter species $( \pm 1 \mathrm{~m})$ (Poderoso et al., 2009). Externally, the nests of $A$. balzani have tubes constructed of fragments of straw and other plant residues and a mound of soil in the form of a semicircle (Figure 1b). This species has external waste disposal chambers that are easily seen and collected, with high potential as a biofertilizer (Santos et al., 2018).

\subsubsection{Turnera subulata Smith (Turneracea)}

The herb T. subulata is a pioneer species, widely distributed and quite common in the study region (Figure 1a). Popularly known as 'flor-do-guarujá' or 'chanana', its populations occur in natural environments, mainly in post-disturbance areas (Arbo, 2005; Arbo et al., 2015). Due to its ease of cultivation and wide occurrence, T. subulata has been used as an ornamental and medicinal plant, especially in the south and southeast of Brazil (Arbo, 2005; Arbo et al., 2015). It is a ruderal species of shrub size, with yellowish flowers and attractive corollas for pollinators (Schlindwein and Medeiros, 2006). It is commonly observed near or even on external chambers of discarding ants (personal observation). It is important to note that the species T. subulata is not part of the list of plant species cut by A. balzani and possibly other species of leaf-cutting ants, in view of the presence of trichomes on its leaves (Kitayama et al., 2010). We consider this herb as a good model to test our hypothesis because it is frequently observed close to A. balzani colonies. 


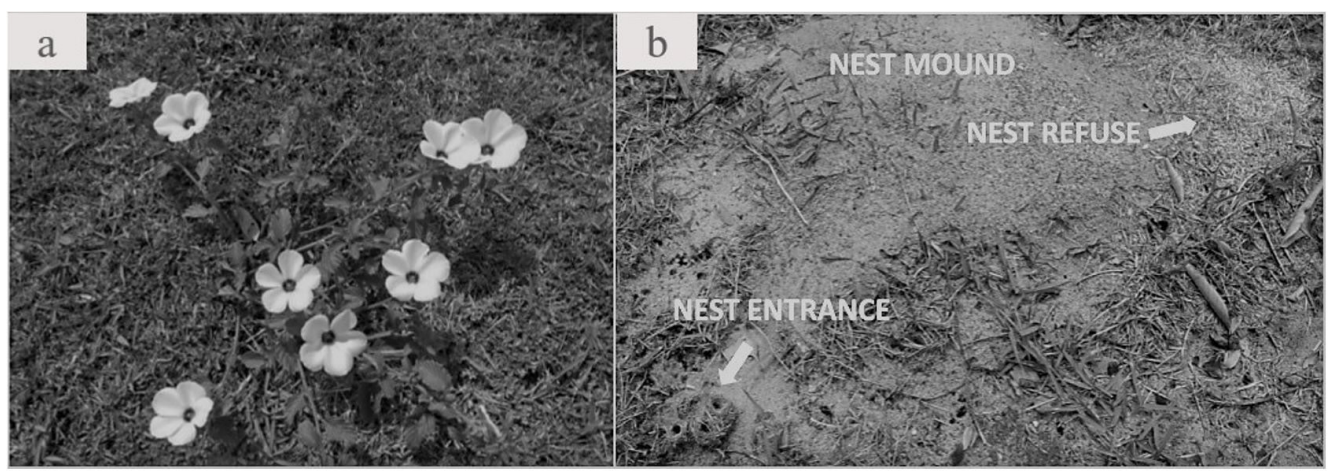

Figure 1. Detail of the studied species. (a) Turnera subulata in the study area; (b) nest mound of Acromyrmex balzani with a nest refuse pile on the right and the colony entrance, characterized by three small straw holes (left).

\subsection{Experimental design}

The experiment was conducted in a greenhouse, located in the Department of Agronomy of the Federal University of Sergipe (UFS), in São Cristóvão, Sergipe, Northeast Brazil ( $10^{\circ} 55^{\prime} 46^{\prime \prime} \mathrm{S}$ and $\left.37^{\circ} 06^{\prime} 13^{\prime \prime} \mathrm{W}\right)$.

The sample design consisted of two treatments: the control treatment (CONT) composed of one litre of soil and the NR treatment, composed of the mixture of CONT + NR by $A$. balzani, in the proportion of $25 \%$ ( $250 \mathrm{~mL}$ ). Both the soil and the NR were obtained in areas of the Campus of the Federal University of Sergipe. We randomly selected 30 colonies of $A$. balzani and collected the NR from the external chambers between August and October 2019. The NR was screened in a stereomicroscope and sieved to remove possible seeds still present and visible soil particles. After that, the substrate was stored in a freezer at $10^{\circ} \mathrm{C}$ until use. The control soil used in the composition of the two treatments was collected in subsamples $(\mathrm{n}=5)$ at a depth of $05-20 \mathrm{~cm}$, respecting a minimum distance of three meters from ant nests. The soil went through the solarization process to inactivate possible pathogens and seeds present (Katan, 2015).

\subsection{Seedling production}

The plants used in the experiment were obtained from seeds collected from 35 individuals of $T$. subulata at the experiment site (UFS/Campus). Sowing was done in polystyrene trays with 128 cells and a volume of $40 \mathrm{~cm}^{3}$, containing only CONT soil. Three seeds were sown per cell. The seedlings were kept for 30 days in the tray with daily irrigation. After 30 days, plants were transferred to 1 -L pots $(n=100)$, containing a layer of crushed stone of $25 \%$ of the container volume to facilitate drainage and $75 \%$ of the volume filled with 50 pots for the CONT and 50 vessels for the NR treatment. The seedlings were kept in a greenhouse with humidity and temperature of $27 \pm 2{ }^{\circ} \mathrm{C}$, and daily watering.

\subsection{Soil analysis}

Five days after transplanting the seedlings, we collected 20 soil samples ( $10 \mathrm{~g}$ ), ten from the NR treatment and ten from the control, to determine the concentration of macronutrients $\mathrm{N}, \mathrm{P}, \mathrm{K}$ and soil organic matter (SOM). These variables were chosen because the content of the NPK formulation is used as a reference in practically all cultivated crops, including ornamental plants (Baligar and Bennett, 1986). Besides, natural soils are generally acidic and low in M.O (Batjes, 1996). Thus, these variables serve as a reference to assess how much NR is able to change these original properties.

All samples were dried in an oven at $60{ }^{\circ} \mathrm{C}$ and sieved through a $2-\mathrm{mm}$ mesh to remove the remaining vegetation and standardise the samples. Nitrogen $(\mathrm{N})$ was determined by Kjeldahl (Dieckow et al., 2007), followed by chamber distillation with hydrochloric acid.

The phosphorus (P) content was determined by the formation of the complex blue phosphorus-molybdic described by Mehlich (1978). The potassium (K) content was quantified by atomic absorption spectrophotometry, based on the Mehlich (1978) extractor. Soil organic matter (SOM) was quantified by converting organic carbon by oxidation with potassium dichromate in sulfuric medium, following the methodology of Anderson and Ingram (1994). Finally, the $\mathrm{pH}$ was determined in $\mathrm{H}_{2} \mathrm{O}$, following the methodology proposed by Raij and Quaggio (1983).

\subsection{Assessment of vegetative development}

At 90 days after transplanting, we evaluated the following characteristics of the plants: total height $(\mathrm{cm})$, stem diameter $(\mathrm{SD})(\mathrm{mm})$, root length $(\mathrm{RL})(\mathrm{cm})$, number of leaves (NL), fresh aboveground biomass (FAB) and dry aboveground biomass (DAB). Plant height, root length and stem diameter were measured with a $0.01 \mathrm{~mm}$ pachymeter.

To determine the FAB, all plants were washed under running water to remove excess soil. Afterwards, the plant aboveground portion was weighed on a digital scale with a precision of $0.001 \mathrm{~g}$. For the measurement of the DAB, the individuals were individually dried in an oven at $60^{\circ} \mathrm{C}$ for 48 hours, and each part was weighed on a digital scale, with an accuracy of $0.001 \mathrm{~g}$.

\subsection{The relative chlorophyll content ( $R C C)$}

The relative chlorophyll content (RCC) in plant leaves is a powerful indicator of foliar nitrogen that may indicate plants with higher nutritional quality (Djumaeva et al., 
2012; Sousa-Souto et al., 2018). The RCC was determined with the aid of a chlorophyll meter (ChlorofiLOG ${ }^{\circledR}$ model CFL 1030) that provides measurements of the contents of chlorophyll a, b and total $(\mathrm{a}+\mathrm{b})$, expressed in RCC units (Barbieri-Junior et al., 2012; Sousa-Souto et al., 2018). Since there were no variations in the proportions of chlorophyll a and b, we considered for analysis only the total chlorophyll content. For the RCC samples, the first three leaves of each plant were evaluated. Measurements were made on the median adaxial part of each of the three leaves of the plant, according to the methodology described in Barbieri-Junior et al. (2012) and Sousa-Souto et al. (2018). Only mature leaves were evaluated, without signs of senescence, signs of predation or presence of pathogens. Three readings were made per plant in all 50 plants per treatment, resulting in a total of 300 RCC measurements. The average chlorophyll value was then calculated for each plant.

Despite having a good correlation with Nitrogen leaf content, RCC is basically used in agronomic research (Barbieri-Junior et al., 2012; Djumaeva et al., 2012) and its use in ecological studies is insipient. Thus, we chose to adopt both measures (RCC and leaf $\mathrm{N}$ analysis) so that the RCC method could be a reference in future ecological research.

\subsection{Analysis of leaf $N$ and $P$ content}

For leaf nutrient analysis ( $\mathrm{N}$ and $\mathrm{P}$ ) we selected 20 plants, ten plants for each treatment. All intact leaves from each sampled plant were used. The leaves were washed in running water and dried in an oven at $60{ }^{\circ} \mathrm{C}$ for 72 hours. The material was ground to a fine powder, weighed on a precision scale (about $2 \mathrm{~g}$ ), and packed in Eppendorf tubes for further analysis. After this procedure, the total nitrogen content of the samples was determined by the Kjeldahl method Dieckow et al. (2007). P levels were obtained by colorimetry, according to Pittman et al. (2005).

\subsection{Statistical analysis}

Differences in soil nutrient content, as well as in the development (height, stem diameter, number of leaves, root length, fresh and dry aboveground biomass) and nutritional variables (leaf nutrient and RCC) of the plants in relation to the treatments were compared by Student's T test or Mann-Whitney (Wilcoxon rank test), according to the normality of the data. The analyzes were performed with the aid of the R software, version 4.0.2 (R Core Team, 2020).

\section{Results}

\subsection{Chemical soil analysis}

The chemical composition of the soil differed statistically between NR and CONT treatments ( $p<0.001$ ). The NR treatment showed high overall increases in the levels of $\mathrm{N}$ (1.45 times), P (2.9 times), K (88.7\%), SOM (2.7 times) and $\mathrm{pH}$ when compared to the CONT treatment (Table 1 ).

\subsection{Analysis of vegetative development}

The soil with NR positively affected all development parameters evaluated (Figure 2). Plants grown with NR showed a $44.14 \%$ increase in stem diameter (Figure 2a), a $49.77 \%$ increase in root length (Figure $2 \mathrm{~b}$ ) and 1.9 times greater plant height as well as a greater number of leaves (Figure $2 \mathrm{c}$ and $2 \mathrm{~d}$ ). There was an increase of 3.6 times in the dry aboveground biomass (Figure 2e), and an 8.5-fold increase in the fresh aboveground biomass (Figure 2f) when compared to the CONT treatment.

\subsection{The relative chlorophyll content (RCC)}

The RCC values of $T$. subulata plants were positively affected by the type of substrate $(\mathrm{p}<0.001)$ (Table 2$)$. The NR treatment plants showed higher levels of chlorophyll with a significant increase of $47.16 \%$ compared to the CONT treatment plants.

\subsection{Analysis of leaf $N$ and $P$ contents}

The analysis of leaf nutrients showed differences between treatments $(\mathrm{p}<0.001)$. Plants of $T$. subulata that grew in the NR treatment showed significantly high values of $\mathrm{P}(71 \%)$ and $\mathrm{N}$ (102\%) compared to the control plants (Table 2).

\section{Discussion}

In the present study, we confirmed the hypothesis tested that plants treated with NR present greater vigour and biomass than non-treated plants and we demonstrated that the beneficial effects of nest refuse go beyond the increase in soil fertility. In just five days after the incorporation of NR into the soil, we observed an increase to about 1.8 to 4 times in the levels of N, P, K and soil organic matter. Such elements are essential for the development of plants, as they accelerate vegetative growth and act in the development and maturation of reproductive structures (Hilhorst and Karssen, 1989; Taiz and Zeiger, 2013; Singh and Reddy, 2014).

Table 1. Mean \pm standard deviation of the contents of macronutrients $(\mathrm{g} / \mathrm{kg})$, soil organic matter $(\mathrm{SOM})$ and $\mathrm{pH}$ between two treatments: Control and nest refuse (NR).

\begin{tabular}{lccccc}
\hline \multicolumn{1}{c}{ Treatment } & $\mathbf{N}$ & $\mathbf{P}$ & $\mathbf{K}$ & SOM & $\mathbf{p H}$ \\
\hline CONT & $0.43 \pm 0.02 \mathbf{b}$ & $32.99 \pm 12.04 \mathbf{b}$ & $0.62 \pm 0.03 \mathbf{b}$ & $0.94 \pm 0.04 \mathbf{b}$ & $3.85 \pm 0.05 \mathbf{b}$ \\
NR & $1.08 \pm 1.83 \mathbf{a}$ & $128.7 \pm 4.11 \mathbf{a}$ & $1.17 \pm 0.1 \mathbf{a}$ & $3.55 \pm 0.22 \mathbf{a}$ & $5.88 \pm 0.1 \mathbf{a}$ \\
\hline
\end{tabular}

CONT: Soil Control; NR: 75\% Soil control + 25\% of NR of A. balzani. N - nitrogen; P - phosphorus; K - potassium; SOM - soil organic matter; $\mathrm{pH}$ - potential of hydrogen. Means followed by equal letters in each column do not differ with a significance level of $5 \%$ ( $\mathrm{t}-\mathrm{test}$; $\mathrm{p}<0.05$ ). 

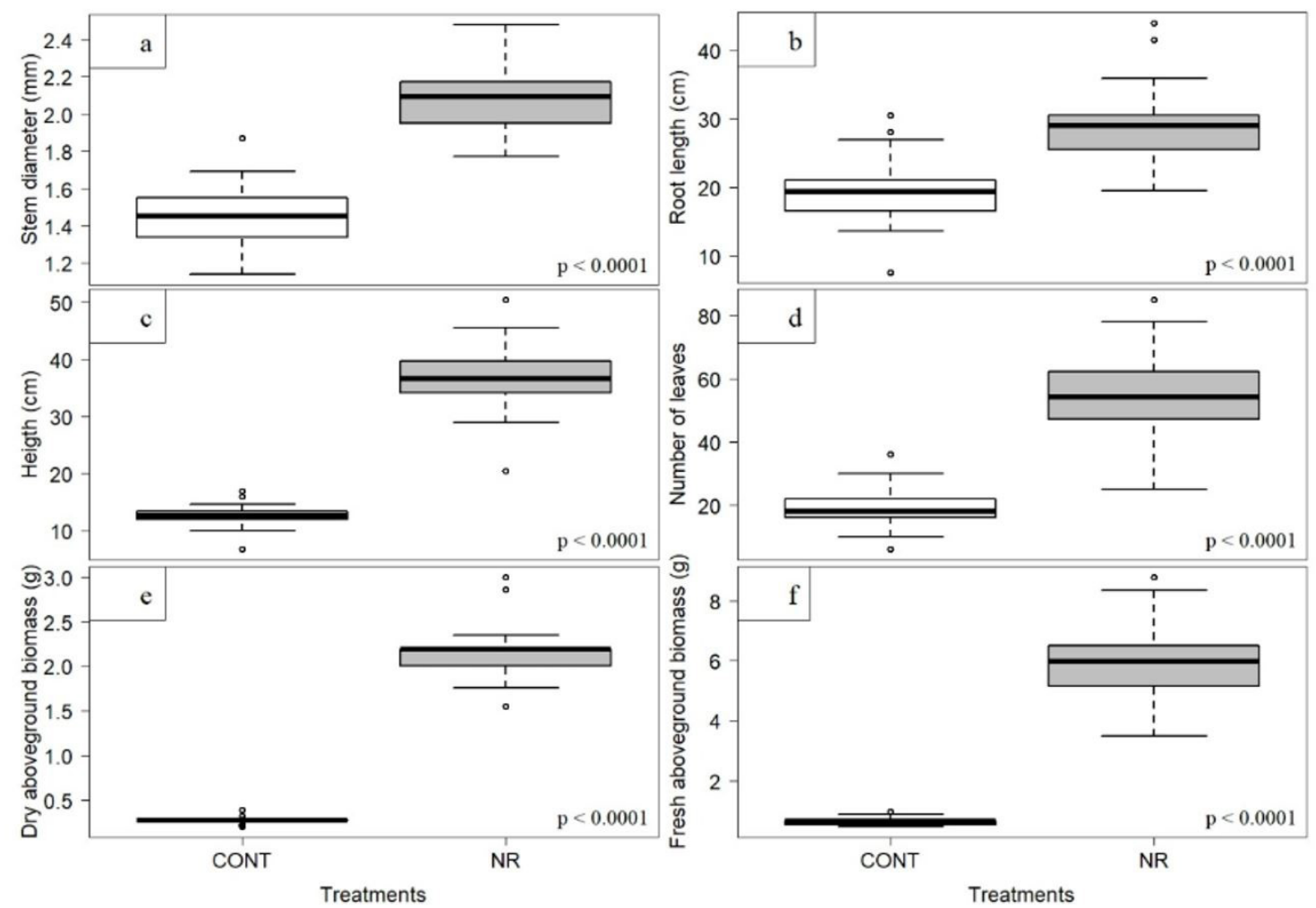

Figure 2. Boxplot of attributes evaluated in T. subulata plants after thirty days between two treatments: (a) stem diameter ( $\mathrm{mm}$ ); (b) root length $(\mathrm{cm})$; (c) plant height $(\mathrm{cm})$, (d) the number of leaves, (e) dry aboveground biomass $(\mathrm{g})$ and $(\mathrm{f})$ fresh aboveground biomass $(\mathrm{g})$. Horizontal lines inside each box indicate the median.

Nitrogen is a key nutrient for the production of several plant species (Pedri et al., 2015). It is a component of many biological compounds that plays an important role in photosynthetic activity (Taiz and Zeiger, 2013; Alvarenga et al., 2019) and its deficiency is one of the main limiting factors for the vegetal development (Shah et al., 2003). Since nitrogen is part of the enzymes associated with chlorophyll synthesis, the chlorophyll concentration reflects the relative status of $\mathrm{N}$ in plant tissues (Chapman and Barreto, 1997). Phosphorus acts directly in the formation of TAP, the "energy unit" of plants (Taiz and Zeiger, 2013; Singh and Reddy, 2015; Alvarenga et al., 2019), and potassium, in turn, participates in osmotic regulation of cells and also in the activation of many enzymes (Hawkesford et al., 2012; Taiz and Zeiger, 2013). In addition, the increase in soil pH in NR treatments helps the mineralization of soil organic matter, which in turn provides greater retention of water and nutrients for plants (Farji-Brener, 2010; Sousa-Souto et al., 2012).

It is unequivocal that NR provides nutrients for plants and that this availability has an impact on their nutritional status (Farji-Brener and Werenkraut, 2015). This fact has already been demonstrated in species of ants that deposit their residues externally, such as Acromyrmex lobicornis (Emery, 1888) (Farji-Brener and Ghermandi, 2008; Farji-Brener, 2010) and Atta colombica
Table 2. Mean \pm standard deviation of the levels of leaf macronutrients $(\mathrm{g} / \mathrm{kg})$ and chlorophyll between treatments.

\begin{tabular}{lccc}
\hline \multirow{2}{*}{ Treatment } & $\mathbf{N}$ & $\mathbf{P}$ & $\mathbf{R C C}$ \\
\cline { 2 - 4 } & $\mathbf{g} / \mathbf{K g}$ & $\mathbf{g ~ k g}^{-3}$ & $\mathbf{~ m g}\left(\mathbf{g ~ M F}^{*}\right)^{-1}$ \\
\hline CONT & $7.48 \pm 0.21 \mathrm{~b}$ & $0.65 \pm 0.14 \mathrm{~b}$ & $28.94 \pm 0.97 \mathrm{~b}$ \\
NR & $12.79 \pm 0.81 \mathbf{a}$ & $1.31 \pm 0.13 \mathbf{a}$ & $42.59 \pm 1.01 \mathbf{a}$
\end{tabular}

CONT: Soil Control; NR: $75 \%$ Soil control $+25 \%$ of NR of A. balzani; $\mathrm{N}$ - nitrogen; P - phosphorus; RCC - relative chlorophyll content. Means followed by equal letters in each column do not differ with a significance level of $5 \%$ (t-test; $\mathrm{p}<0.05$ ). ${ }^{*} \mathrm{MF}$ - fresh matter.

(Guérin-Méneville, 1844) (Haines, 1978). Another previous study demonstrated the role of NR as islands of colonization of herbaceous species and their role in increasing plant biomass (Santos et al., 2019). The presence of NR not only improves the nutritional quality of the soil but also allows rapid assimilation and improvement in plant nutritional aspects, increasing the content of nutrients in the tissues and the rate of photosynthesis. The present study not only confirms such benefits occurring both at the soil level (increased soil fertility) and the individual plant level (higher content of leaf nutrients), but also shows that the presence of NR in the soil alters other nutritional responses, such as an increase in the relative chlorophyll content (RCC). 
Several studies show that there is a strong relationship between the chlorophyll content and the nutritional content of leaves, especially for $\mathrm{N}$ and $\mathrm{P}$, since most of the content is allocated to the photosynthetic apparatus (Taiz and Zeiger, 2013; Rodrigues et al., 2014; Sá et al., 2017). Leaf chlorophyll concentration is often well correlated with plant metabolic activity (e.g., photosynthetic capacity and RuBP carboxylase activity), as well as leaf $\mathrm{N}$ concentration (Evans, $1983 ; 1989)$. This relationship is particularly important in dystrophic habitats, where the levels of N, P and K available in the soil are extremely low and some plant species, such as herbaceous, generally tend to allocate more of these nutrients to photosynthetic structures (Amorim and Batalha, 2008; Hawkesford et al., 2012; Malik and Rengel, 2013; Souza et al., 2016). Particularly, since NR increases the content of nutrients and chlorophyll in the leaves, it is possible that it provides greater photosynthetic efficiency of plants in contact with this substrate, either through facilitating $\mathrm{CO}_{2}$ absorption or greater RuBP activity, which is common in the initial phase of vegetative development in herbaceous plants (Centritto et al., 1999; Bhatt et al., 2010).

The positive effect of NR of leaf-cutting ants on vegetation can vary depending on the species involved and the plant stratum. For species of ants that discard NR in mounds outside the nest, such as A. balzani, the effects can be observed in the herbaceous strata, as seen in $T$. subulata. However, considering the species of ants that discard waste in underground chambers, such as most Atta and Acromyrmex species in Brazil, the same positive effects can occur only in the shrub or tree strata. This observation was initially proposed by Coutinho (1984), who suggested a possible ecological role of fire and the activities of leaf-cutting ants in the cycling of nutrients in Brazilian savannas (cerrado). In this study, the author proposes a complementary effect in which fire would benefit the herbaceous layer and the activities of ants would benefit the tree layer. The results presented here and seen also in a study at field level (Santos et al., 2019) indicate that Coutinho's (1984) hypothesis must be updated. Thus, ants that dispose of waste externally can directly benefit the herbaceous layer, regardless of the presence of natural fires.

The results presented here indicate the role that NR from A. balzani plays by incorporating nutrients into the soil and increasing the development of an herbaceous species, indicating that this substrate has the potential to be used as a natural fertiliser especially for herbaceous species and other species with short life cycles. Such results reflect the greater fertility of the soil with NR and the rapid assimilation of these nutrients by plants, indicating that T. subulata performs better in these soils, despite being adapted to the conditions of soils with low natural fertility (Arbo, 2005; Arbo et al., 2015).

Our results suggest an indirect way in which leaf-cutting ants, through the production of organic waste, can benefit plants by promoting positive changes in its development and nutritional status (Pirk and Farji- Brener, 2013). In addition, the plants that access the NR of leaf-cutting ants can not only improve physical and nutritional performance but can also benefit reproductive performance (fitness), for example, with greater production of flowers, fruits and seeds, as well as increased germination rate (Santos et al., 2019). In short, the high nutritional quality of NR, the positive effects observed in the development of native plants or for commercial use in greenhouse cultivation (this study, Santos et al., 2018) or at the field level (Santos et al., 2019), make NR a potentially important natural fertilizer with multiple uses.

\section{Conclusion}

The presence of NR of $A$. balzani in the soil provided an increase in the nutrient content of the soil with rapid availability for the plants, considering the short period of the experiment. This natural fertilizer contributed to the production of more vigorous plants, with a higher content of chlorophyll and leaf nutrients when compared to the control treatment. As it is relatively abundant and easy to collect, the NR of nests of $A$. balzani has the potential to be used as an alternative substrate in the production of shortlife cycle plants.

\section{Acknowledgements}

The authors would like to thank Letícia Bezerra, José Marques Nascimento and Geovanna Amaral for their valuable assistance in conducting the experiment. To the entire team of the Laboratory of Water and Soil Analysis at the Federal University of Sergipe, for their help in the chemical analysis of the substrates and the availability of the necessary structure to carry out the experiment, especially to Kairon Rocha. To Dr. Marcos Vinícius Meiado for the valuable suggestions for improving the experimental design. Funding Information: Coordenação de Aperfeiçoamento de Pessoal de Nível Superior (CAPES/PROAP and CAPES/FAPITEC $\left.-n^{\circ} 88881.157451 / 2017-01\right)$ and (Ed.EDITAL POSGRAP/COPGD/UFS № 06/2020).

\section{References}

ALHO, C.J.R., 2008. The value of biodiversity. Brazilian Journal of Biology = Revista Brasileira de Biologia, vol. 68, no. 4, (suppl.), pp. 1115-1118. http://dx.doi.org/10.1590/S1519-69842008000500018. PMid:19197481.

ALVARENGA, C.F.S., SILVA, E.M., NOBRE, R.G., GHEYI, H.R., LIMA, G.S. and SILVA, L.A., 2019. Morphophysiology of West Indian cherry irrigated with salt water under combination of doses of nitrogen and potassium. Agrária, vol. 42, no. 1, pp. 191-200. http://dx.doi. org/10.19084/RCA18215.

AMORIM, P.K. and BATALHA, M.A., 2008. Soil chemical factors and grassland species density in Emas National Park (central Brazil). Brazilian Journal of Biology = Revista Brasileira de Biologia, vol. 68, no. 2, pp. 279-285. http://dx.doi.org/10.1590/S151969842008000200008. PMid:18660955.

ANDERSON, J. and INGRAM, J., 1994. Tropical soil biology and fertility: a handbook of methods. Soil Science, vol. 157, no. 4, pp. 157-265. http://dx.doi.org/10.1097/00010694-199404000-00012.

ARBO, M.M., 2005. Estudios sistemáticos en Turnera (Turneraceae). III. Series Anomalae y Tunera. Bonplandia, vol. 14, no. 3-4, pp. 115-318. http://dx.doi.org/10.30972/bon.143-41382. 
ARBO, M.M., GONZALEZ, A.M. and SEDE, S.M., 2015. Phylogenetic relationships within Turneraceae based on morphological characters with emphasis on seed micromorphology. Plant Systematics and Evolution, vol. 301, no. 7, pp. 1907-1926. http:// dx.doi.org/10.1007/s00606-015-1204-3.

BALIGAR, V. and BENNETT, O., 1986. NPK-fertilizer efficiency: a situation analysis for the tropics. Fertilizer Research, vol. 10 pp. 147-164. https://doi.org/10.1007/BF01074369.

BARBIERI-JUNIOR, E., ROSSIELLO, R.O.P., SILVA, R.V.M.M., RIBEIRO, R.C. and MORENZ, M.J.F., 2012. Um novo clorofilômetro para estimar os teores de clorofila em folhas do capim tifton 85 . Ciência Rural, vol. 42, no. 12, pp. 2242-2245. http://dx.doi. org/10.1590/S0103-84782012005000109.

BATJES, N.H., 1996. Total carbon and nitrogen in the soils of the world. European Journal of Soil Science, vol. 47, no. 2, pp. 151163. http://dx.doi.org/10.1111/j.1365-2389.1996.tb01386.x.

BHATT, R.K., BAIG, M.J. and TIWARI, H.S., 2010. Elevated $\mathrm{CO}_{2}$ influences photosynthetic characteristics of Avena sativa L. cultivars. Journal of Environmental Biology, vol. 31, no. 5, pp. 813-818.

BREARLEY, F.Q., PRESS, M.C. and SCHOLES, J.D., 2003. Nutrients obtained from leaf litter can improve the growth of dipterocarp seedlings. The New Phytologist, vol. 160, no. 1, pp. 101-110. http:// dx.doi.org/10.1046/j.1469-8137.2003.00851.x. PMid:33873536.

CENTRITTO, M., MAGNANI, F., LEE, H.S.J. and JARVIS, P.G., 1999. Interactive effects of elevated $\mathrm{CO}_{2}$ and drought on cherry (Prunus avium) seedlings II. Photosynthetic capacity and water relations. The New Phytologist, vol. 141, no. 1, pp. 141-153. http://dx.doi. org/10.1046/j.1469-8137.1999.00327.x.

CERDA, N.V., TADEY, M., FARJI-BRENER, A.G. and NAVARRO, M.C., 2012. Effects of leaf-cutting ant refuse on native plant performance under two levels of grazing intensity in the Monte Desert of Argentina. Applied Vegetation Science, vol. 15, no. 4, pp. 479-487. http://dx.doi.org/10.1111/j.1654-109X.2012.01188.x.

CHAPMAN, S.C. and BARRETO, H.J., 1997. Using a chlorophyll meter to estimate specific leaf nitrogen of tropical maize during vegetative growth. Agronomy Journal, vol. 89, no. 4, pp. 557-562. http://dx.doi.org/10.2134/agronj1997.0002196 $2008900040004 x$

CLEVELAND, C.C., HOULTON, B.Z., SMITH, W.K., MARKLEIN, A.R., REED, S.C., PARTON, W., DEL-GROSSO, S.J. and RUNNING, S.W., 2013. Patterns of new versus recycled primary production in the terrestrial biosphere. Proceedings of the National Academy of Sciences of the United States of America, vol. 110, no. 31, pp. 12733-12737. http://dx.doi.org/10.1073/pnas.1302768110. PMid:23861492.

CORREA, M.M., SILVA, P.S., WIRTH, R., TABARELLI, M. and LEAL, I.R., 2010. How leaf-cutting ants impact forests: drastic nest effects on light environment and plant assemblages. Oecologia, vol. 162, no. 1, pp. 103-115. http://dx.doi.org/10.1007/s00442009-1436-4. PMid:19690891.

COUTINHO, L.M., 1984. Aspectos ecológicos da saúva no Cerrado - a saúva, as queimadas e sua possível relação na ciclagem de nutrientes minerais. Boletim de Zoologia da Universidade de São Paulo, vol. 8, no. 8, pp. 1-9. http://dx.doi.org/10.11606/ issn.2526-3358.bolzoo.1984.122116.

DALLING, J.W., HEINEMAN, K., GONZALEZ, G. and OSTERTAG, R., 2016. Geographic, environmental and biotic sources of variation in the nutrient relations of tropical montane forests. Journal of Tropical Ecology, vol. 32, no. 5, pp. 368-383. http://dx.doi. org/10.1017/S0266467415000619.

DELAVAUX, C.S., CAMENZIND, T., HOMEIER, J., JIMÉNEZ-PAZ, R., ASHTON, M. and QUEENBOROUGH, A.S., 2017. Nutrient enrichment effects on mycorrhizal fungi in an Andean tropical montane forest. Mycorrhiza, vol. 27, no. 4, pp. 311-319. http:// dx.doi.org/10.1007/s00572-016-0749-5. PMid:27924430.

DIECKOW, J., MIELNICZUK, J., KNICKER, H., BAYER, C., DICK, D.P. and KÖGEL-KNABNER, I., 2007. Comparison of carbon and nitrogen determination methods for samples of a Paleudult subjected to no-till cropping systems. Scientia Agrícola, vol. 64, no. 5, pp. 532-540. http://dx.doi.org/10.1590/S0103-90162007000500011.

DJUMAEVA, D., LAMERS, J.P.A., MARTIUS, C. and VLEK, P.L.G., 2012. Chlorophyll meters for monitoring foliar nitrogen in three tree species from arid Central Asia. Journal of Arid Environments, vol. 85, pp. 41-45. http://dx.doi.org/10.1016/j.jaridenv.2012.03.008.

EVANS, J.R., 1983. Nitrogen and photosynthesis in the flag leaf of wheat (Triticum aestivum L.). Plant Physiology, vol. 72, no. 2, pp. 297-302. http://dx.doi.org/10.1104/pp.72.2.297. PMid:16662996.

EVANS, J.R., 1989. Photosynthesis and nitrogen relationships in leaves of $C_{3}$ plants. Oecologia, vol. 78, no. 1, pp. 9-19. http:// dx.doi.org/10.1007/BF00377192. PMid:28311896.

FARJI-BRENER, A.G. and GHERMANDI, L., 2008. Leaf-cutter ant nests near roads increase fitness of exotic plant species in natural protected areas. Proceedings. Biological Sciences, vol. 275, no. 1641, pp. 1431-1440. http://dx.doi.org/10.1098/rspb.2008.0154. PMid:18364316.

FARJI-BRENER, A.G. and WERENKRAUT, V., 2015. A meta-analysis of leaf-cutting ant nest effects on soil fertility and plant performance. Ecological Entomology, vol. 40, no. 2, pp. 150-158. http://dx.doi.org/10.1111/een.12169.

FARJI-BRENER, A.G. and WERENKRAUT, V., 2017. The effects of ant nests on soil fertility and plant performance: a meta-analysis. The Journal of Animal Ecology, vol. 86, no. 4, pp. 866-877. http:// dx.doi.org/10.1111/1365-2656.12672. PMid:28369906.

FARJI-BRENER, A.G., 2010. Leaf-cutting ant nests and soil biota abundance in a semi-arid steppe of northwestern Patagonia. Sociobiology, vol. 56, no. 2, pp. 549-557.

FERNANDEZ, A., TADEY, M. and FARJI-BRENER, A.G., 2018. Refuse attracts? Effect of refuse dumps of leaf cutting ants on floral traits. Austral Ecology, vol. 44, no. 1, pp. 70-77. http://dx.doi. org/10.1111/aec.12653.

HAINES, B.L., 1978. Element and energy flows through colonies of the leaf-cutting ant, Atta Colombica, in Panama. Biotropica, vol. 10, no. 4, pp. 270-277. http://dx.doi.org/10.2307/2387679.

HAWKESFORD, M., HORST, W., KICHEY, T., LAMBERS, H., SCHJOERRING, J., MOLLER, T.S. and WHITE, P., 2012. Functions of macronutrients. In: P. MARSCHNER, eds. Marschner's mineral nutrition of higher plants. New York: Elsevier, pp. 135-189. http:// dx.doi.org/10.1016/B978-0-12-384905-2.00006-6.

HILHORST, H.W.M. and KARSSEN, C.M., 1989. Nitrate reductase independent stimulation of seed germination in Sisymbrium officinale L. (hedge mustard) by light and nitrate. Annals of Botany, vol. 63, no. 1, pp. 131-137. http://dx.doi.org/10.1093/ oxfordjournals.aob.a087715.

KATAN, J., 2015. Soil solarization: the idea, the research and its development. Phytoparasitica, vol. 43, no. 1, pp. 1-4. http:// dx.doi.org/10.1007/s12600-014-0419-0.

KITAYAMA, K., SOUSA-SOUTO, L., HAY, J.D., OTTONI, R.J.V. and AQUINO, P.P.U., 2010. Trichomes and Atta sexdens (Hymenoptera: Formicidae): a study of foraging behavior in the laboratory. Sociobiology, vol. 55, no. 1, pp. 107-116.

LAVELLE, P., 1997. Faunal activities and soil processes: adaptive strategies that determine ecosystem function. Advances in Ecological Research, vol. 27, pp. 93-132. http://dx.doi.org/10.1016/ S0065-2504(08)60007-0. 
MALIK, I. and RENGEL, Z., 2013. Physiology of nitrogen-use efficiency. In: Z. RENGEL, ed. Improving water and nutrient-use efficiency in food production systems. Hoboken: John Wiley and Sons. pp. 105-121. http://dx.doi.org/10.1002/9781118517994.ch7.

MEHLICH, A., 1978. Influence of fluoride, sulfate and acidity on extractable phosphorus, calcium, magnesium and potassium. Communications in Soil Science and Plant Analysis, vol. 9, no. 6, pp. 455-476. http://dx.doi.org/10.1080/00103627809366823.

MEYER, S., LEAL, I., TABARELLI, M. and WIRTH, R., 2011. Performance and fate of tree seedlings on and around nests of the leafcutting ant Atta cephalotes: ecological filters in a fragmented forest. Austral Ecology, vol. 36, no. 7, pp. 79-790. http://dx.doi. $\operatorname{org} / 10.1111 / \mathrm{j} .1442-9993.2010 .02217 . x$.

MEYER, S.T., NEUBAUER, M., SAYER, E.J., LEAL, I.R., TABARELLI, M. and WIRTH, R., 2013. Leaf-cutting ants as ecosystem engineers: topsoil and litter perturbations around Atta cephalotes nests reduce nutrient availability. Ecological Entomology, vol. 38, no. 5, pp. 497-504. http://dx.doi.org/10.1111/een.12043.

MOUTINHO, P., NEPSTAD, D. and DAVIDSON, E., 2003. Influence of leaf-cutting ant nests on secondary forest growth and soil properties in Amazonia. Ecology, vol. 84, no. 5, pp. 1265-1276. http://dx.doi.org/10.1890/0012-9658(2003)084[1265:IOLA NO]2.0.CO;2.

NEILL, C., FRY, B., MELILLO, J.M., STEUDLER, P.A., MORAES, J.F.L. and CERRI, C.C., 1996. Forest- and pasture-derived carbon contributions to carbon stocks and microbial respiration of tropical pasture soils. Oecologia, vol. 107, no. 1, pp. 113-119. http://dx.doi.org/10.1007/BF00582241. PMid:28307198.

NEILL, C., PICCOLO, M.C., STEUDLER, P.A., MELILLO, J.M., FEIGL, B.J. and CERRI, C.C., 1995. Nitrogen dynamics in soils of forests and active pastures in the western Brazilian Amazon Basin. Soil Biology E' Biochemistry, vol. 27, no. 9, pp. 1167-1175. http:// dx.doi.org/10.1016/0038-0717(95)00036-E.

PEDRI, Z.C., LOZANO, L.M.S., HERMANN, K.L., HELM, C.V., PERALTA, R.M. and TAVARES, L.B.B., 2015. Influence of nitrogen sources on the enzymatic activity and grown by Lentinula edodes in biomass Eucalyptus benthamii. Brazilian Journal of Biology = Revista Brasileira de Biologia, vol. 75, no. 4, pp. 940-947. http:// dx.doi.org/10.1590/1519-6984.03214. PMid:26675911.

PIRK, I.G. and FARJI-BRENER, A.G., 2013. Can the nutrient-rich soil patches created by leaf-cutting ants favor plant compensation for foliar damage? A test of the compensatory continuum hypothesis. Plant Ecology, vol. 214, no. 8, pp. 1059-1070. http:// dx.doi.org/10.1007/s11258-013-0231-9.

PITTMAN, J.J., ZHANG, H., SCHRODER, J.L. and PAYTON, M.E., 2005. Differences of phosphorus in Mehlich 3 extracts determined by colorimetric and spectroscopic methods. Communications in Soil Science and Plant Analysis, vol. 36, no. 11-12, pp. 1641 1659. http://dx.doi.org/10.1081/CSS-200059112.

PODEROSO, J.C.M., RIBEIRO, G.T., GONÇALVES, G.B., MENDONÇA, P.D., POLANCZYK, R., ZANETTI, R., SERRÃO, J.E. and ZANUNCIO, J.C., 2009. Nest and foraging characteristics of Acromyrmex landolti balzani (Hymenoptera: Formicidae) in northeast Brazil. Sociobiology, vol. 54, no. 2, pp. 361-371.

R CORE TEAM, 2020 [viewed 19 October 2020]. $R$ : a language and environment for statistical computing [online]. Vienna, Austria: R Foundation for Statistical Computing. Available from: http:// www.R-project.org/

RAIJ, B. and QUAGGIO, J.A. 1983. Métodos de análise de solo para fins de fertilidade. Campinas: Instituto Agronômico, 31 p.

RANDO, J.S.S. and FORTI, L.C., 2005. Ocorrência de formigas Acromyrmex Mayr, 1865, em alguns municípios do Brasil. Acta
Scientiarum. Biological Sciences, vol. 27, no. 2, pp. 129-133. http:// dx.doi.org/10.4025/actascibiolsci.v27i2.1322.

RODRIGUES, M.A., FRESCHI, L., PEREIRA, P.N. and MERCIER, H., 2014. Interactions between nutrients and crassulacean ac id metabolism. Progress in Botany, vol. 75, pp. 167-186. http:// dx.doi.org/10.1007/978-3-642-38797-5_6.

SÁ, F.V.S., GHEYI, H.R., LIMA, G.S., PAIVA, E.P., FERNANDES, P.D., MOREIRA, R.C.L., SILVA, L.D.A. and NETO, M.F., 2017. Water relations and gas exchanges of west Indian cherry under salt stress and nitrogen and phosphorus doses. The Journal of Agricultural Science, vol. 9, no. 9, pp. 168-177. http://dx.doi. org/10.5539/jas.v9n10p168.

SANTOS, R.S., GUERRA, M.B.B., AMBROGI, B.G. and SOUSA-SOUTO, L., 2018. Nest refuse of leaf-cutting ants as a growing substrate for organic farming systems. Organic Agriculture, vol. 8, no. 4, pp. 315-324. http://dx.doi.org/10.1007/s13165-017-0199-1.

SANTOS, R.S., HAUM BARROS MECENAS, H. and SOUSA-SOUTO, L.., 2019. Nest refuse of Atta opaciceps (Hymenoptera: Formicidae) increases plant biomass and diversity during the regrowth of herbaceous species. Applied Soil Ecology, vol. 133, pp. 160-165. http://dx.doi.org/10.1016/j.apsoil.2018.10.002.

SCHLINDWEIN, C. and MEDEIROS, P., 2006. Pollination in Turnera subulata (Turneraceae): unilateral reproductive dependence of the narrowly oligolectic bee Protomeliturga turnerae (Hymenoptera, Andrenidae). Flora - Morphology, Distribution, Functional Ecology of Plants, vol. 201, no. 3, pp. 178-188. http:// dx.doi.org/10.1016/j.flora.2005.07.002.

SHAH, Z., SHAH, S.H., PEOPLES, M.B., SCHWENKE, G.D. and HERRIDGE, D.F., 2003. Crop residue and fertilizer $\mathrm{N}$ effects on nitrogen fixation and yields of legume-cereal rotations and soil organic fertility. Field Crops Research, vol. 83, no. 1, pp. 1-11. http://dx.doi.org/10.1016/S0378-4290(03)00005-4.

SINGH, S.K. and REDDY, V.R., 2014. Combined effects of phosphorus nutrition and elevated carbon dioxide concentration on chlorophyll fluorescence, photosynthesis and nutrient efficiency of cotton. Journal of Plant Nutrition and Soil Science, vol. 177, no. 6, pp. 892-902. http://dx.doi.org/10.1002/jpln.201400117.

SINGH, S.K. and REDDY, V.R., 2015. Response of carbon assimilation and chlorophyll fluorescence to soybean leaf phosphorus across $\mathrm{CO}_{2}$ : alternative electron sink, nutrient efficiency and critical concentration. Journal of Photochemistry and Photobiology. B, Biology, vol. 151, pp. 276-284. http://dx.doi.org/10.1016/j. jphotobiol.2015.08.021. PMid:26343044.

SOUSA-SOUTO, L., BOCCHIGLIERI, A., DIAS, D.M., FERREIRA, A.S. and FILHO, J.P.L., 2018. Changes in leaf chlorophyll content associated with flowering and its role in the diversity of phytophagous insects in a tree species from a semiarid Caatinga. PeerJ, vol. 6, pp. e5059. http://dx.doi.org/10.7717/peerj.5059. PMid:30042875.

SOUSA-SOUTO, L., GUERRA, M.B.B., AMBROGI, B.G. and PEREIRAFILHO, E.R., 2012. Nest refuse of leaf-cutting ants mineralize faster than leaf fragments: results from a field experiment in northeast Brazil. Applied Soil Ecology, vol. 61, pp. 131-136. http://dx.doi.org/10.1016/j.apsoil.2012.05.005.

SOUSA-SOUTO, L., SCHOEREDER, J.H., SCHAEFER, C.E.G.R. and SILVA, W.L., 2008. Ant nests and soil nutrient availability: the negative impact of fire. Journal of Tropical Ecology, vol. 24, no. 6, pp. 639-646. http://dx.doi.org/10.1017/S0266467408005464.

SOUSA-SOUTO, L., VIANA-JUNIOR, A.B. and NASCIMENTO, E.S., 2013. Spatial distribution of Acromyrmex balzani (Emery) (Hymenoptera: Formicidae: Attini) nests using two sampling methods. Sociobiology, vol. 60, no. 2, pp. 162-168. http://dx.doi. org/10.13102/sociobiology.v60i2.162-168. 
SOUZA, J.P., MELO, N.M.J., PEREIRA, E.G., HALFELD, A.D., GOMES, I.N. and PRADO, C.H.B.A., 2016. Responses of woody Cerrado species to rising atmospheric $\mathrm{CO}_{2}$ concentration and water stress: gains and losses. Functional Plant Biology, vol. 43, no. 12, pp. 1183-1193. http://dx.doi.org/10.1071/FP16138. PMid:32480537.

STERNBERG, L.S.L, PINZON, M.C., MOREIRA, M.Z., MOUTINHO, P., ROJAS, E.I. and HERRE, E.A., 2007. Plants use macronutrients accumulated in leaf - cutting ant nests. Proceedings. Biological Sciences, vol. 274, no. 1608, pp. 315-321. http://dx.doi. org/10.1098/rspb.2006.3746. PMid:17164194.
TAIZ, L. and ZEIGER, E., 2013. Nutrientes essenciais, deficiências e distúrbios vegetais. In: L. TAIZ and E. ZEIGER, eds. Fisiologia vegetal. Porto Alegre: Artmed, pp. 96-103.

WALKER, T. and SYERS, J., 1976. The fate of phosphorus during pedogenesis. Geoderma, vol. 15, no. 1, pp. 1-19. http://dx.doi. org/10.1016/0016-7061(76)90066-5.

WIRTH, R., MEYER, S.T., ALMEIDA, W.R., ARAUJO-JUNIOR, M.V., BARBOSA, V.S. and LEAL, I.R., 2007. Increasing densities of leaf-cutting ants (Atta spp.) with proximity to the edge in a Brazilian Atlantic forest. Journal of Tropical Ecology, vol. 23, no. 4, pp. 501-505. http://dx.doi.org/10.1017/S0266467407004221. 